\title{
Incidence and Risk Factors for Severe Pneumonia in Children Hospitalized with Pneumonia in Ujjain, India
}

\author{
Sunil Kumar Kasundriya ${ }^{1,2}$, Mamta Dhaneria ${ }^{1}$, Aditya Mathur ${ }^{1}\left(\mathbb{D}\right.$ and Ashish Pathak ${ }^{1,3,4, * \mathbb{C}}$ \\ 1 Department of Pediatrics, Ruxmaniben Deepchand Gardi Medical College, \\ Ujjain 456006, Madhya Pradesh, India; praskujn8001@gmail.com (S.K.K.); \\ mamtadhaneria@gmail.com (M.D.); dr.adityamathur121@gmail.com (A.M.) \\ 2 All India Institute of Medical Science, Raipur 492001, Chhattisgarh, India \\ 3 Department of Women and Children's Health, International Maternal and Child Health Unit, \\ Uppsala University, SE-751 85 Uppsala, Sweden \\ 4 Global Health-Health Systems and Policy: Medicines, Focusing Antibiotics, \\ Department of Public Health Sciences, Karolinska Institutet, SE-171 76 Stockholm, Sweden \\ * Correspondence: ashish.pathak@ki.se; Tel.: +91-93-0223-9899
}

Received: 20 May 2020; Accepted: 24 June 2020; Published: 27 June 2020

\begin{abstract}
Childhood pneumonia is a major public health problem. The aim of this prospective hospital-based study is to determine the incidence and risk factors for community-acquired severe pneumonia in children in Ujjain, India. The study includes 270 children, 161 (60\%) boys and $109(40 \%)$ girls, aged between 2 months and 5 years with World Health Organization defined and radiologically confirmed severe pneumonia. Considering the 270 children, $64 \%$ (95\% confidence interval (CI) 57.9-69.4) have severe pneumonia. The following are identified as risk factors for severe pneumonia from the generalized logistic regression model: Born premature (adjusted odds ratio (AOR) 7.50; 95\% CI 2.22-25.31; $p=0.001$ ); history of measles (AOR 6.35; 95\% CI 1.73-23.30; $p=0.005$ ); incomplete vaccination (AOR 2.66; 95\% CI 1.09-6.48; $p=0.031$ ); acyanotic congenital heart disease (AOR 9.21; 95\% CI 2.29-36.99; $p=0.002$ ); home treatment tried (AOR 3.84; 95\% CI 1.42-10.39; $p=0.008$ ); living in a kuchha house (AOR 3.89; 95\% CI 1.51-10.01; $p=0.027$ ); overcrowding (AOR 4.50; 95\% CI 1.75-11.51; $p=0.002$ ); poor ventilation in living area (AOR 16.37; 95\% CI 4.67-57.38; $p<0.001$ ); and practicing open defecation (AOR 16.92; 95\% CI 4.95-57.85; $p<0.001$ ). Awareness of these risk factors can reduce mortality due to severe pneumonia.
\end{abstract}

Keywords: risk factors; community acquired pneumonia; severe pneumonia; children

\section{Introduction}

Pneumonia is the most common illness affecting infants and children globally. It is the most common cause of under-5 (U-5) mortality and contributes to 15\% of U-5 mortality in 2017, killing an estimated 808,920 children [1]. World Health Organization (WHO) data indicate that acute respiratory infections (ARIs) are the second most common cause of disability-adjusted life years lost around the world [1]. During the Millennium Development Goal era from 2000 to 2015, the WHO-led ARI control program reduced the burden of pneumonia deaths from 1.7 million annual cases to 0.9 million, a $30 \%$ decrease in burden [2]. During the same time, the pneumonia mortality rate decreased by nearly $51 \%[3,4]$.

The ARI control program is dependent on the early identification and treatment of children with signs and symptoms suggestive of pneumonia, presuming a bacterial etiology. The WHO and United Nations Children's Fund (UNICEF), in 2013, published the integrated Global Action Plan for Pneumonia and Diarrhea (GAPPD), which outlined a framework for ending preventable child 
deaths due to diarrhea and pneumonia by 2025 [2]. The GAPPD emphasizes a "protect, prevent, treat" approach and includes proven effective interventions [2]. However, estimates suggest that the sustainable development goal to eliminate preventable child deaths by 2030 will remain improbable unless deaths due to childhood pneumonia are significantly reduced [5].

However, more knowledge on the risk factors affecting the severity of pneumonia is required to reduce deaths from childhood pneumonia. Studies from low/middle-income countries (LMICs) have tried to identify the risk factors for severe pneumonia [6-17], but only a few studies from India have reported the risk factors for severe pneumonia $[6,8,13]$. More clinical studies from India are needed as the country alone contributes to $32 \%$ of the annual global burden of pediatric pneumonia [18]. India had the highest number of global U-5 deaths due to pneumonia with an estimated 508 deaths per day in 2017 [18]. No clinical study on the risk factors for child pneumonia has been published from the state of Madhya Pradesh (MP), India. Since MP has one of the highest infant and childhood mortalities in India [19], the present study has been undertaken to fill the evidence gap on the risk factors for severe child pneumonia. The aim of this study is to develop recommendations for appropriate interventions to address the demographic, socioeconomic, and environmental risk factors for severe pneumonia in children in the age range of 1-59 months in Ujjain, MP, India.

\section{Materials and Methods}

\subsection{Study Setting}

The study was conducted from July 2015 to June 2016 in the pediatric wards of C.R. Gardi Hospital (CRGH)—a 720 bed teaching hospital attached to R.D. Gardi Medical College, Ujjain, which is managed by a charitable trust.

\subsection{Study Participants and Outcome Measure}

Consecutive children aged from 2 to 59 months, admitted in the pediatric ward or pediatric intensive care unit, were screened for pneumonia by two pediatricians. The pneumonia cases were defined by fast breathing or tachypnoea as delineated by the WHO (in children 2-12 months of age, breathing rate $\geq 50$ cycles per minute; in children $12-59$ months of age, breathing rate $\geq 40$ cycles per minute) and chest indrawing [20].

The outcome measure for the study was "severe pneumonia" and was defined according to the WHO as a child aged 2-59 months with cough and/or difficulty breathing along with any of the danger signs such as inability to drink, persistent vomiting, convulsions, lethargy, unconsciousness, stridor in a calm child, severe acute malnutrition and hypoxemia defined as oxygen saturation $(\mathrm{SaO} 2)(<90 \%)$ on fingertip pulse oximetry [21]. Apart from the above definition, other inclusion criterian were: a) First symptoms within the last 14 days and $b$ ) children with radiologically confirmed pneumonia as per WHO guidelines [17]. These children were included in the study after obtaining informed consent from the parents. Children admitted to other hospitals, those treated with intravenous or intramuscular antibiotics within the last $24 \mathrm{~h}$, children with positive HIV status, and children administered steroids within the last month were excluded from the study.

\subsection{Definitions Used in the Study}

The definitions used in the study are provided in Supplementary Material Table S1.

\subsection{Data Collection Method}

$\mathrm{SaO}_{2}$ was measured on admission by trained clinical assistants using a fingertip pulse oximeter (ChoicemmedMD300CN356, ChoiceMMed Technology, New Delhi, India). The mother or caregiver accompanying the child fulfilling the inclusion criteria (tachypnoea plus hypoxemia on fingertip pulse oximeter) was interviewed by one of the research assistants to fill a predefined questionnaire. The questionnaire contained information on the signs and symptoms of pneumonia on admission, 
demographics of the child and mother, relevant history, history of the treatment received before hospitalization, and environment-related risk factors for pneumonia (Appendix A). Two independent pediatric consultants assessed each child and reached an agreement on the severity of pneumonia. All children included in the study were managed according to the India Clinical Epidemiology Network (IndiaCLEN) Task Force on Pneumonia guidelines [21].

\subsection{Laboratory Investigations}

Laboratory investigation, apart from X-ray for confirmation of pneumonia, included absolute leukocyte count, absolute neutrophil count, and C-Reactive Protein (CRP). Extreme leukocytosis was defined as a absolute leukocyte count above or equal to $25,000 / \mathrm{mm}$ and moderate leukocytosis was defined as a count between $15,000-24,999 / \mathrm{mm}$ [22]. Neutrophil percentage was calculated using a peripheral smear examination. The lower cut-off value for CRP was defined as $20 \mathrm{mg} / \mathrm{dL}$ [23]. Blood samples were drawn by venepuncture at time of admission. Blood cell count was performed using the 5-part coulter counter H 550 Transasia (Mumbai, India). CRP serum level was measured by the immunoturbidimetric assay using the Tulip Diagnostics Ltd. (Nagpur, India).

\subsection{Sample Size Calculation}

A study from Lucknow, India reported that nearly $20 \%$ of children presenting with fast breathing were diagnosed with severe pneumonia [24]. To calculate the sample size for the present study, we assumed the proportion of severe pneumonia as $20 \%$ or 0.2 . The sample size calculation was done to detect at least $15 \%$ precision around the proportion of $20 \%$ or 0.2 with a power of 80 and a two-sided alpha of 0.05 . Thus, the calculated minimum sample size was 151 children with severe pneumonia.

\subsection{Data Management and Statistical Analysis}

Data from paper forms was entered into EpiData Entry (Version 3.1, EpiData Software Association, Odense, Denmark). Data were analyzed using Stata (Version 13.0, Statacorp. TX, USA). The outcome variable was severe pneumonia. The association between independent variables (risk factors) and the outcome variable of severe pneumonia was evaluated in 2-by-2 tables using the Pearson chi-square test. The results of the 2-by-2 tables with each independent risk factor were reported as unadjusted odd ratios.

To develop the final reported model, stepwise multivariate logistic regression models with backward elimination of the independent variables having $p$ values more than 0.1 were used. The independent variables of age and gender were kept in the final model even if their $p$ values were more than 0.1. The final model reports the adjusted odd ratios (AORs) and their $95 \%$ confidence intervals (CIs). A $p$ value of less than 0.05 was considered significant. Model discrimination was conducted using the C-statistics-receiver-operating-characteristics curve [25]. The predictive power of the final and initial models were compared using the following two statistical methods: Akaike information criterion (AIC) calculated as [AIC $=-2 \log$ maximum likelihood $+2 \times$ degrees of freedom (df)] [26]; Bayesian information criterion (BIC) which was calculated as [BIC $=-2$ log maximum likelihood $+\log ($ sample size $) \times d f$ ] [27]. The study was approved by the institutional ethics committee of R.D. Gardi Medical College, Ujjain (Institution Ethics Committee reference number 2013).

\section{Results}

During the study period, 270 children with pneumonia ( $60 \%$ boys and $40 \%$ girls), with the mean [ \pm standard deviation (SD)] age of $18.5( \pm 17.5)$ months were enrolled. Figure 1 provides the flow chart of the patient recruitment process. Considering the 270 children, 172 children were diagnosed with severe pneumonia, and the remaining 98 children had pneumonia according to the WHO classification. The prevalence of severe pneumonia was, thus, $63.7 \%$ (95\% CI 57.9-69.4). The signs and symptoms at the time of admission are shown in Table 1. 
Table 1. Signs and symptoms at presentation in hospitalized children with severe pneumonia $(n=270)$ in Ujjain, India.

\begin{tabular}{|c|c|c|c|}
\hline Signs/Symptoms & $\begin{array}{c}\text { Total } \\
n=270(\%)\end{array}$ & $\begin{array}{c}\text { Pneumonia } \\
n=98(\%)\end{array}$ & $\begin{array}{c}\text { Severe Pneumonia } \\
\quad n=172(\%)\end{array}$ \\
\hline Fast breathing ${ }^{\text {a }}$ & $258(95)$ & $96(98)$ & $172(100)$ \\
\hline Chest indrawing/difficulty in breathing ${ }^{a}$ & $255(94)$ & $93(95)$ & $162(94)$ \\
\hline Not able to drink ${ }^{a}$ & $238(88)$ & $85(87)$ & $153(89)$ \\
\hline Persistent vomiting a & $159(59)$ & $42(43)$ & $117(68)$ \\
\hline Convulsions ${ }^{a}$ & $11(4)$ & $5(6)$ & $6(3)$ \\
\hline Lethargic/Unconscious ${ }^{a}$ & $39(14)$ & $19(19)$ & $20(12)$ \\
\hline Stridor in a calm child ${ }^{a}$ & $28(10)$ & $8(8)$ & $20(12)$ \\
\hline Severe acute malnutrition ${ }^{a}$ & $113(42)$ & $77(79)$ & $86(21)$ \\
\hline Cyanosis $b$ & $42(16)$ & $2(2)$ & $40(23)$ \\
\hline Toxic look $b$ & $43(16)$ & $22(22)$ & $21(12)$ \\
\hline Severe pallor $(\mathrm{Hb}<7 \mathrm{gm} / \mathrm{dL})^{b}$ & $41(15)$ & $17(17)$ & $24(14)$ \\
\hline Severe dehydration $\mathrm{b}$ & $34(13)$ & $3(3)$ & $31(18)$ \\
\hline Shock $\mathrm{b}$ & $21(8)$ & $2(2)$ & $19(11)$ \\
\hline Meningeal irritation ${ }^{b}$ & $17(6)$ & $12(12)$ & $5(3)$ \\
\hline Crepitations & $199(74)$ & $57(58)$ & $142(83)$ \\
\hline Low grade fever $\left(37^{\circ} \mathrm{C}-38^{\circ} \mathrm{C}\right)$ & $188(70)$ & $55(56)$ & $133(77)$ \\
\hline High grade fever $\left(>38^{\circ} \mathrm{C}\right)$ & $82(30)$ & $43(43)$ & $39(23)$ \\
\hline Diarrhea & $91(34)$ & $16(16)$ & $75(44)$ \\
\hline Significant lymphadenopathy & $84(34)$ & $44(16)$ & $40(23)$ \\
\hline Running nose & $68(25)$ & $14(14)$ & $54(31)$ \\
\hline Wheeze & $54(20)$ & $27(28)$ & $27(16)$ \\
\hline Ear discharge & $39(14)$ & $19(19)$ & $20(12)$ \\
\hline
\end{tabular}

${ }^{a}$ danger signs according to $\mathrm{WHO} ;{ }^{b}$ other danger signs, $\%$ column percentage.

Total number of children seen as outpatients during the study period, $\mathrm{n}=31,052$

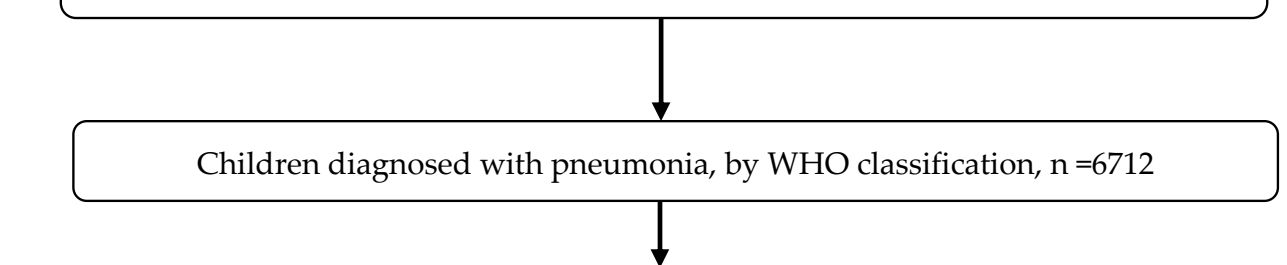

Children with pneumonia by WHO classification plus saturation $(\mathrm{SaO} 2)(<90 \%)$ onfinger-tip pulse oximetry, eligible for admission and recruitment, $\mathrm{n}=610$

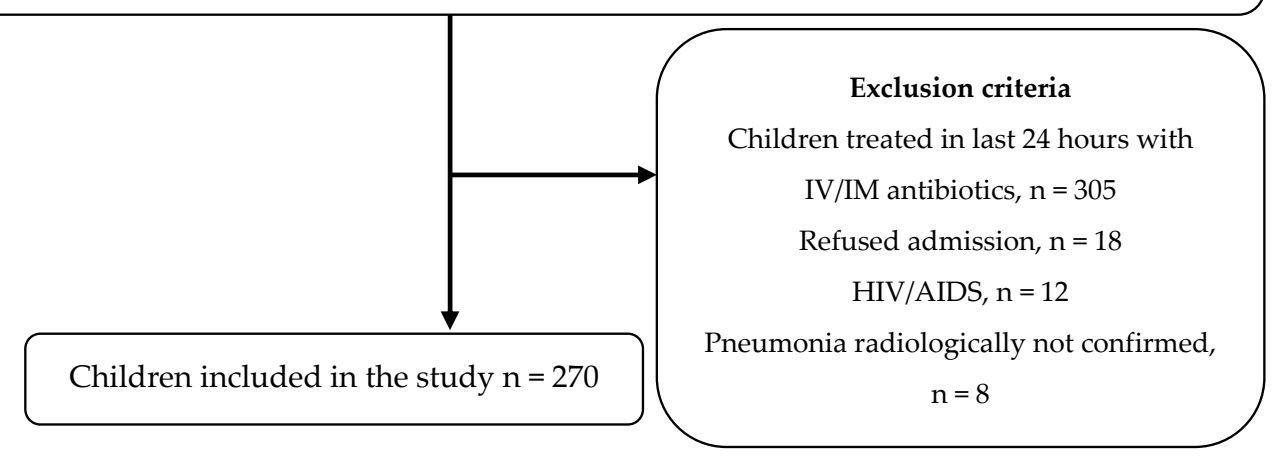

Figure 1. Flow chart of the patient recruitment process. WHO- World Health Organization, IV-Intravenous, IM-Intramuscular, HIV-Human Immunodeficiency Virus, AIDS-Acquired Immunodeficiency Syndrome. 
The mean $( \pm \mathrm{SD})$ duration of signs and symptoms before admission was $4( \pm 2.1)$ days. A total of $38(14 \%)$ children required ventilatory support for a mean $( \pm \mathrm{SD})$ duration of $36( \pm 5) \mathrm{h}$. Complicated pneumonia was diagnosed in $17(6 \%)$ children, and $16(6 \%)$ children died during the hospital stay.

\subsection{Results of Bivariate Analysis}

The association of socio-demographic and birth-related risk factors with severe pneumonia is depicted in Table 2. The table depicts that age less thanone-year, rural residence, premature birth (before 37 weeks of gestational age), and non-working mother increased the risk of severe pneumonia.

Table 2. Bivariate associations of socio-demographic and birth-related covariates with severe pneumonia in hospitalized children $(n=270)$ in Ujjain, India.

\begin{tabular}{|c|c|c|c|c|c|c|}
\hline $\begin{array}{l}\text { Independent } \\
\text { Variable }\end{array}$ & $\begin{array}{c}\text { Total } \\
n= \\
270(\%)\end{array}$ & $\begin{array}{c}\text { Severe } \\
\text { Pneumonia } \\
n=172(\%)\end{array}$ & $\begin{array}{l}\text { Pneumonia } \\
n=98,(\%)^{\#}\end{array}$ & OR & $95 \%$ CI & $p$ Value \\
\hline \multicolumn{7}{|l|}{$\begin{array}{l}\text { Age (in } \\
\text { months) }\end{array}$} \\
\hline $2-12$ & 149 (55) & $83(48)$ & $66(67)$ & $\mathrm{R}$ & $\mathrm{R}$ & - \\
\hline $13-60$ & $121(45)$ & $89(52)$ & $32(33)$ & 2.21 & $1.31-3.71$ & 0.003 \\
\hline \multicolumn{7}{|l|}{ Gender } \\
\hline Boys & $161(60)$ & $103(60)$ & $58(59)$ & $\mathrm{R}$ & $\mathrm{R}$ & - \\
\hline Girls & $109(40)$ & $69(40)$ & $40(41)$ & 0.97 & $0.58-1.60$ & 0.910 \\
\hline \multicolumn{7}{|l|}{ Residence } \\
\hline Urban & $100(37)$ & $56(33)$ & $44(45)$ & $\mathrm{R}$ & $\mathrm{R}$ & - \\
\hline Rural & $170(63)$ & $116(67)$ & $54(55)$ & 1.68 & $1.01-2.81$ & 0.044 \\
\hline \multicolumn{7}{|l|}{$\begin{array}{l}\text { Born } \\
\text { premature }\end{array}$} \\
\hline No & $56(21)$ & $9(5)$ & $47(48)$ & $\mathrm{R}$ & $\mathrm{R}$ & - \\
\hline Yes & $214(79)$ & $163(95)$ & $51(52)$ & 16.6 & $7.65-36.38$ & $<0.001$ \\
\hline \multicolumn{7}{|l|}{$\begin{array}{l}\text { Born term } \\
\text { low birth } \\
\text { weight }\end{array}$} \\
\hline No & $214(79)$ & $147(85)$ & $67(68)$ & $\mathrm{R}$ & $\mathrm{R}$ & - \\
\hline Yes & $56(21)$ & $25(15)$ & $31(32)$ & 0.36 & $0.20-0.67$ & 0.001 \\
\hline \multicolumn{7}{|l|}{$\begin{array}{l}\text { Mother's } \\
\text { education }\end{array}$} \\
\hline Illiterate & $26(10)$ & $11(6)$ & $15(15)$ & $\mathrm{R}$ & $\mathrm{R}$ & - \\
\hline $\begin{array}{l}\text { Upto } \\
\text { secondary }\end{array}$ & $225(83)$ & $148(86)$ & 77 (79) & 2.62 & $1.14-5.98$ & 0.022 \\
\hline Graduate & $19(07)$ & $13(8)$ & $06(6)$ & 2.95 & $0.85-10.22$ & 0.087 \\
\hline \multicolumn{7}{|l|}{$\begin{array}{l}\text { Mother's } \\
\text { occupation }\end{array}$} \\
\hline Working & $33(12)$ & $9(5)$ & $24(24)$ & $\mathrm{R}$ & $\mathrm{R}$ & - \\
\hline Nonworking & $237(88)$ & 163(95) & $74(76)$ & 0.17 & $0.07-0.38$ & $<0.001$ \\
\hline
\end{tabular}

The association of history-related risk factors with severe pneumonia is shown in Table 3. Factors such as non-exclusive breast feeding in the first 6 months, lack of vitamin A supplementation, incomplete immunization, kerosene ingestion in the past 1 month, hospitalization in the past 1 month, and trial of home remedy for present episode of pneumonia increased the risk of severe pneumonia (Table 3). 
Table 3. Bivariate associations between past history-related covariates and severe pneumonia in hospitalized children $(n=270)$ in Ujjain, India.

\begin{tabular}{|c|c|c|c|c|c|c|}
\hline Independent variable & $\begin{array}{c}\text { Total } \\
n= \\
270(\%)\end{array}$ & $\begin{array}{c}\text { Severe } \\
\text { Pneumonia } \\
n=172(\%)\end{array}$ & $\begin{array}{l}\text { Pneumonia } \\
n=98,(\%)^{\#}\end{array}$ & OR & $95 \%$ CI & $p$ Value \\
\hline \multicolumn{7}{|l|}{$\begin{array}{c}\text { Exclusive } \\
\text { breastfeeding }\end{array}$} \\
\hline Yes & $216(80)$ & $125(73)$ & $91(93)$ & $\mathrm{R}$ & $\mathrm{R}$ & - \\
\hline No & $54(20)$ & $47(27)$ & $7(7)$ & 4.88 & $2.11-11.30$ & $<0.001$ \\
\hline \multicolumn{7}{|l|}{$\begin{array}{c}\text { Vitamin A } \\
\text { supplementation }\end{array}$} \\
\hline Given & $225(83)$ & $139(81)$ & $86(88)$ & $\mathrm{R}$ & $\mathrm{R}$ & - \\
\hline Not given & $45(17)$ & $33(19)$ & $12(12)$ & 1.70 & $0.83-3.47$ & 0.144 \\
\hline \multicolumn{7}{|l|}{ Measles * } \\
\hline No & $209(77)$ & $123(72)$ & $86(88)$ & $\mathrm{R}$ & $\mathrm{R}$ & - \\
\hline Yes & $61(23)$ & $49(28)$ & $12(12)$ & 2.85 & $1.43-5.68$ & 0.003 \\
\hline \multicolumn{7}{|l|}{$\begin{array}{l}\text { Incomplete } \\
\text { vaccination }\end{array}$} \\
\hline No & $132(49)$ & $59(34)$ & $73(74)$ & $\mathrm{R}$ & $\mathrm{R}$ & - \\
\hline Yes & $138(51)$ & $113(66)$ & $25(26)$ & 5.59 & $3.21-9.71$ & $<0.001$ \\
\hline \multicolumn{7}{|l|}{ Kerosene ingestion ** } \\
\hline No & $235(87)$ & $143(83)$ & $92(94)$ & $\mathrm{R}$ & $\mathrm{R}$ & - \\
\hline Yes & $35(13)$ & $29(17)$ & $6(6)$ & 3.10 & $1.24-7.78$ & 0.015 \\
\hline \multicolumn{7}{|l|}{ Antibiotic treatment $* *$} \\
\hline No & $204(76)$ & $125(73)$ & $79(81)$ & $\mathrm{R}$ & $\mathrm{R}$ & - \\
\hline Yes & $66(24)$ & $47(27)$ & $19(19)$ & 1.56 & $0.85-2.85$ & 0.146 \\
\hline \multicolumn{7}{|l|}{ Hospitalization ** } \\
\hline No & $212(79)$ & $125(73)$ & $87(89)$ & $\mathrm{R}$ & $\mathrm{R}$ & - \\
\hline Yes & $58(21)$ & $47(27)$ & $11(11)$ & 2.97 & $1.46-6.05$ & 0.003 \\
\hline \multicolumn{7}{|l|}{$\begin{array}{c}\text { Acyanotic congenital } \\
\text { heart disease }\end{array}$} \\
\hline Absent & $241(89)$ & $150(87)$ & $91(93)$ & $\mathrm{R}$ & $\mathrm{R}$ & - \\
\hline Present & $29(11)$ & $22(13)$ & $7(7)$ & 1.90 & $0.78-4.64$ & 0.153 \\
\hline \multicolumn{7}{|l|}{ Home treatment tried } \\
\hline Yes & $86(32)$ & $26(15)$ & $60(61)$ & $\mathrm{R}$ & $\mathrm{R}$ & - \\
\hline No & $184(68)$ & $146(85)$ & $38(39)$ & 8.86 & $4.95-15.87$ & $<0.001$ \\
\hline
\end{tabular}

OR—odds ratios, CI-Confidence interval, ${ }^{*}$ history of measles in the last 6 months, ${ }^{* *}$ Measles history during the past month, ${ }^{\#-C o l u m n}$ percentage, $\mathrm{R}$ - referent category.

The association between environmental covariates and severe pneumonia is depicted in Table 4 . Factors such as nuclear family, kuccha house, overcrowding, indoor air pollution, poor ventilation in living area, household tuberculosis contact, and open-air defecation increased the risk of severe pneumonia.

\subsection{Results of Total Leukocyte Count, Neutrophil Percentage and CRP}

The mean ( \pm standard deviation) TLC count among children with pneumonia and severe pneumonia was $13,425( \pm 389) ; 95 \%$ CI $12,653-14,197$ and $13,851( \pm 333) ; 95 \%$ CI $13,194-14,508$, respectively $(p<0.001)$. Considering 270 children, $52 \%(n=112)$ had normal leukocyte counts, $41 \%(n=112)$ had moderate leukocytosis, and $7 \%(n=18)$ had extreme leukocytosis. Severe pneumonia patients had significantly more moderate leukocytosis compared to pneumonia patients ( $78 \%$ versus $22 \%$, respectively, $p<0.05)$. Extreme leukocytosis was observed more commonly in pneumonia $(61 \%)$ versus severe pneumonia (39\%), but the difference was not statistically significant $(p=0.48)$. The mean 
neutrophil count among children with pneumonia and severe pneumonia was $68( \pm 1.64)$; $95 \%$ CI $66-72$ and $68( \pm 1.27) ; 95 \%$ CI 66-71. The difference was not statistically significant $(p=0.051)$.

Table 4. Bivariate associations between environmental covariates and severe pneumonia in hospitalized children $(n=270)$ in Ujjain, India.

\begin{tabular}{|c|c|c|c|c|c|c|}
\hline Independent Variable & $\begin{aligned} & \text { Total } \\
n= & 270(\%)\end{aligned}$ & $\begin{array}{c}\text { Severe } \\
\text { Pneumonia } \\
n=172(\%)\end{array}$ & $\begin{array}{c}\text { Pneumonia } \\
n=98,(\%)\end{array}$ & OR & $95 \% \mathrm{CI}$ & $p$ Value \\
\hline \multicolumn{7}{|l|}{ Type of family } \\
\hline Nuclear & $136(50)$ & $68(40)$ & $68(69)$ & $\mathrm{R}$ & $\mathrm{R}$ & - \\
\hline Joint & $134(50)$ & $104(60)$ & $30(30)$ & 3.46 & $2.04-5.87$ & $<0.001$ \\
\hline \multicolumn{7}{|l|}{$\begin{array}{c}\text { Number of family } \\
\text { members }\end{array}$} \\
\hline Upto 5 & $131(49)$ & $68(40)$ & $63(64)$ & $\mathrm{R}$ & $\mathrm{R}$ & - \\
\hline $5-10$ & $116(43)$ & $86(50)$ & $30(31)$ & 2.65 & $1.51-4.55$ & $<0.001$ \\
\hline$>10$ & $23(8)$ & $18(10)$ & $5(5)$ & 3.33 & $1.61-9.51$ & 0.024 \\
\hline \multicolumn{7}{|l|}{ Type of home } \\
\hline Pukka & 101(37) & $56(33)$ & $45(46)$ & $\mathrm{R}$ & $\mathrm{R}$ & - \\
\hline Kuccha & $169(63)$ & $116(67)$ & $53(54)$ & 1.75 & $1.05-2.92$ & 0.030 \\
\hline \multicolumn{7}{|l|}{ Overcrowding } \\
\hline No & $82(30)$ & $32(19)$ & $50(51)$ & $\mathrm{R}$ & $\mathrm{R}$ & - \\
\hline Yes & $188(70)$ & $140(81)$ & $48(49)$ & 4.55 & $2.62-7.91$ & $<0.001$ \\
\hline \multicolumn{7}{|l|}{ Indoor air pollution } \\
\hline No & $73(27)$ & $30(17)$ & $43(44)$ & $\mathrm{R}$ & $\mathrm{R}$ & - \\
\hline Yes & 197(73) & $142(83)$ & $55(56)$ & 3.70 & $2.11-6.48$ & $<0.001$ \\
\hline \multicolumn{7}{|l|}{$\begin{array}{c}\text { Poor ventilation in } \\
\text { living area }\end{array}$} \\
\hline No & $69(26)$ & $14(8)$ & $55(56)$ & $\mathrm{R}$ & $\mathrm{R}$ & - \\
\hline Yes & $201(74)$ & $158(92)$ & $43(44)$ & 14.43 & 7.33-28.39 & $<0.001$ \\
\hline \multicolumn{7}{|l|}{ Contact with TB } \\
\hline No & $44(16)$ & $20(12)$ & $24(24)$ & $\mathrm{R}$ & $\mathrm{R}$ & - \\
\hline Yes & $226(84)$ & $152(88)$ & $74(76)$ & 2.46 & $1.28-4.74$ & 0.007 \\
\hline \multicolumn{7}{|l|}{ Smoking at home } \\
\hline No & $112(41)$ & $72(42)$ & $40(41)$ & $\mathrm{R}$ & $\mathrm{R}$ & - \\
\hline Yes & $158(59)$ & $100(58)$ & $58(59)$ & 0.95 & $0.57-1.58$ & 0.867 \\
\hline \multicolumn{7}{|l|}{ Drinking water source } \\
\hline Underground water & $112(41)$ & $69(40)$ & $43(44)$ & $\mathrm{R}$ & $\mathrm{R}$ & - \\
\hline Tap water & $158(59)$ & $103(60)$ & $55(56)$ & 1.16 & $0.70-1.92$ & 0.547 \\
\hline \multicolumn{7}{|l|}{ Open defecation } \\
\hline No & $176(65)$ & $90(52)$ & $86(88)$ & $\mathrm{R}$ & $\mathrm{R}$ & - \\
\hline Yes & $94(35)$ & $82(48)$ & $12(12)$ & 6.52 & $3.32-12.81$ & $<0.001$ \\
\hline
\end{tabular}

OR—odds ratios, CI-Confidence interval, ${ }^{\#-C o l u m n}$ percentage, $\mathrm{R}$-referent category.

The mean CRP value among children with pneumonia and severe pneumonia was $14.13( \pm 0.59)$; 95\% CI 12.95-15.32 and $21.38( \pm 0.56) ; 95 \%$ CI 20.26-22.51, respectively $(p<0.001)$. The cut-off of $20 \mathrm{mg} / \mathrm{L}$ had a sensitivity of $63 \%$, specificity of $90 \%$, positive predictive value of $92 \%$, and negative predictive value of $58 \%$ and correctly classified non severe pneumonia from severe pneumonia in $73 \%$ of cases.

\subsection{Results of Multivariate Logistic Regression Analysis}

Table 5 depicts the results of the backward logistic regression model. The risk factors identified in the final model included: age (continuous variable); gender (boys versus girls); born premature 
(no versus yes); history of measles in the last 6 months (no versus yes); incomplete vaccination (no versus yes); acyanotic congenital heart disease (absent versus present); home treatment tried (yes versus no);type of home (pukka versus kuccha); overcrowding (no versus yes); poor ventilation in living area (no versus yes); open defecation (no versus yes).

Table 5. Multivariate analyses of socio-demographic, past treatment-related, environmental, and signand symptom-related risk factors of severe pneumonia in hospitalized children $(n=270)$ in Ujjain, India.

\begin{tabular}{cccc}
\hline Independent Variables & AOR & $\mathbf{9 5 \%}$ CI & $p$ Value \\
\hline Age in months \# (continuous) & 1.00 & $0.97-1.02$ & 0.832 \\
Gender ${ }^{\text {(boys versus girls) }}$ & 0.74 & $0.30-1.79$ & 0.514 \\
Born premature (no versus yes) & 7.50 & $2.22-25.31$ & 0.001 \\
Measles *(no versus yes) & 6.35 & $1.73-23.30$ & 0.005 \\
Incomplete vaccination(no versus yes) & 2.66 & $1.09-6.48$ & 0.031 \\
Acyanotic congenital heart disease(no versus yes) & 9.21 & $2.29-36.99$ & 0.002 \\
Home treatment tried (yes versus no) & 3.84 & $1.42-10.39$ & 0.008 \\
Type of home(pukka versus kuccha) & 3.89 & $1.51-10.01$ & 0.027 \\
Overcrowding (no versus yes) & 4.50 & $1.75-11.51$ & 0.002 \\
Poor ventilation in living area(no versus yes) & 16.37 & $4.67-57.38$ & $<0.001$ \\
Open defecation(no versus yes) & 16.92 & $4.95-57.85$ & $<0.001$ \\
\hline
\end{tabular}

AOR- adjusted odds ratios, ${ }^{\#}$ Adjusted for age and sex, ${ }^{*}$ History of measles in the last 6 months.

\subsection{Model Discrimination}

The initial model characteristics were $\mathrm{df}=29, \mathrm{AIC}=183.6$, and $\mathrm{BIC}=287.9$, whereas the final model characteristics were $\mathrm{df}=12, \mathrm{AIC}=171.6, \mathrm{BIC}=214.8$. Therefore, the predictive power of the final model was significantly better than that of the initial model.

\section{Discussion}

The present study included children with WHO-defined symptoms and other signs to define pneumonia and severe pneumonia [2]. The other included signs which were part of the initial assessment, and whose values were ascertained by other studies, were cyanosis, toxic look, severe pallor $(\mathrm{Hb}<7 \mathrm{gm} / \mathrm{dL})$, severe dehydration, shock, and meningeal irritation [28-30].

During our study, severe pneumonia was more common in children between two and 12 months of age compared with children between 13 and 60 months of age. The global prevalence of pneumonia is highest in the age group of 1-4 years [18]. Children residing in rural areas were more affected with severe pneumonia compared with children living in urban areas, and the condition showed a marked male predilection. Similar findings have been reported in other regions of India and other neighboring countries like Bhutan and Nepal [31,32].

The present study reported that prematurely born children had an increased risk of severe pneumonia. Similar results were reported in another community-based study [33]. The underlying reason could be the effects of premature birth, such as poor infant feeding, and the resultant failure of childhood growth. A decrease in growth failure indices such as stunting and wasting can bring about a significant decrease in pneumonia mortality [18]. Pneumonia developed in $4-9.6 \%$ of children with post-measles infection, depending on whether they received antibiotic treatment [34]. This cause of pneumonia, thus, can be prevented by prioritization of measles vaccination along with pneumococcal conjugate vaccine (PCV) and haemophilus influenzae type B (HIB) vaccine. PCV was not introduced in the duration of the study; however, the HIB vaccine was given as part of the pentavalent vaccine. During the present study, the children that did not receive vaccines covered in the expanded program of immunization had an increased risk of severe pneumonia. Respiratory infections were less common among children who were completely immunized than in children with incomplete immunization [18]. The increased global HIB vaccination between 1990 and 2017 reduced the U-5 mortality by $11.4 \%$, which is the maximum among all known interventions [18]. Children having 
congenital heart disease (CHD) had an increased risk of severe pneumonia in our study. A left-to-right shunt is expected to have an increased risk of pneumonia and heart failure. A Nigerian study, which included 121 children with pneumonia, reported 14 (11.5\%) having a CHD [35]. Children who received any home treatment had an increased risk of severe pneumonia in the present study. This could be due to greater prescription of antibiotics in the study area [36,37]. Treatment with inappropriate antibiotics could have increased the risk of severe pneumonia.

Among the environmental risk factors, children living in kuccha houses had an increased risk of severe pneumonia. Kuccha houses are typically built by the poor and is a recognized risk factor for pneumonia in other Asian countries as well [31,32]. Overcrowding and poorly ventilated living areas were identified as risk factors for severe pneumonia. Higher levels of outdoor pollution in urban areas [18,38], high levels of solid fuel use causing indoor pollution in rural areas, and poorly constructed houses were the main reasons for the increased risk of pneumonia in children in our study [18,39]. LMICs that implemented measures to decrease exposure to household air pollution reduced pneumonia mortality by around $8 \%$, but increased exposure to ambient air pollution increased mortality by around $4 \%$ [18]. Although open air defecation is not directly related to childhood pneumonia, it may be a common risk factor for both diarrhea and pneumonia as proposed by the WHO [2].

The present study evaluated host biomarkers like theTLC count, which was useful only in the presence of moderate leukocytosis. Generally, like the conclusion in other studies, it can be concluded that TLC and neutrophil percentage were not useful in distinguishing pneumonia from severe disease [40]. However, a CRP cut-off of $20 \mathrm{mg} / \mathrm{L}$ had a high specificity (90\%) and positive predictive value (92\%) to distinguish non-severe from severe disease. Thus, a CRP more than $20 \mathrm{mg} / \mathrm{L}$ might have some utility in predicting severe pneumonia in our and similar settings.

A primary limitation of this study was that the study did not ascertain the etiology of pneumonia in children, because it was not the primary study objective. Other limitations included the absence of blood investigations of the children due to the non-specific nature of the leukocyte count and C-reactive proteins in distinguishing pneumonia from severe pneumonia and the non-presentation of antibiotic use data as all children were managed using standard IndiaCLEN treatment guidelines. Another limitation of the study is the data are from a single teaching hospital. The results are generalizable to similar resource-limited settings, but hospital-to-hospital variations are expected.

\section{Conclusions}

Childhood pneumonia has been identified as the major "forgotten killer of children" by UNICEF and the WHO. Multiple modifiable risk factors for severe pneumonia have been identified in this study. Pediatricians and other health care workers, including the grassroot health workers, should be aware of these risk factors of severe pneumonia when managing the patient with pneumonia. The management of the modifiable risk factors may reduce mortality due to severe pneumonia.

Supplementary Materials: The following are available online at http://www.mdpi.com/1660-4601/17/13/4637/s1, Table S1: title-Definitions used in the study.

Author Contributions: S.K.K., M.D., A.M. and A.P. participated inthe conception and design of the study. S.K.K. and A.M. collected the data. A.M. and A.P. did data management. A.P. supervised the data collection. S.K.K., A.M. and A.P. performed the statistical analysis. S.K.K. and A.P. drafted the manuscript. S.K.K., A.M, M.D., and A.P. revised the paper critically for substantial intellectual content. All authors have read and agreed to the published version of the manuscript.

Funding: This study is funded by Uppsala Universitet's L R Åkerhams post-doctoral scholarship in clinical research, obtained by Ashish Pathak. The funders had no role in study design, data collection, data analysis, decision to publish, or preparation of the manuscript.

Acknowledgments: We are thankful to all the study participants for taking part in the study. We would also like to thank the Dean, M.K. Rathore, and Medical Director, V.K. Mahadik, R.D. Gardi Medical College, Ujjain for the support that was provided us in undertaking the study.

Conflicts of Interest: The authors declare no conflict of interest. 


\section{Appendix A}

\section{(A). Basic Demographic Information}

1. Enrolment number

2. Date of the form filling

3. Name Surname

4. Date of birth

5. Age in months

6. Sex Male $\square \quad$ Female $\square$

7. IPD number

8. Date of admission

9. Date of discharge/death

10. Residence Rural $\square \quad$ Urban

(B). Signs and symptoms at presentation in hospitalized children with severe pneumonia

\begin{tabular}{|c|c|c|}
\hline Signs/symptoms & Yes & No \\
\hline Fast breathing & & \\
\hline Chest indrawing/difficulty in breathing & & \\
\hline Not able to drink & & \\
\hline Persistent vomiting & & \\
\hline Convulsions & & \\
\hline Lethargic/Unconscious & & \\
\hline Stridor in a calm child & & \\
\hline Severe acute malnutrition & & \\
\hline Cyanosis & & \\
\hline Toxic look & & \\
\hline Severe pallor $(\mathrm{Hb}<7 \mathrm{gm} / \mathrm{dL})$ & & \\
\hline Severe dehydration & & \\
\hline Shock & & \\
\hline Meningeal irritation & & \\
\hline Crepitations & & \\
\hline $\begin{array}{l}\text { Fever } \\
{\left[\text { Low grade fever }\left(37^{\circ} \mathrm{C}-38^{\circ} \mathrm{C}\right) \text { High grade fever }\left(>38^{\circ} \mathrm{C}\right)\right]}\end{array}$ & & \\
\hline Diarrhea & & \\
\hline Significant lymphadenopathy & & \\
\hline Running nose & & \\
\hline Wheeze & & \\
\hline Ear discharge & & \\
\hline
\end{tabular}


(C). Socio-demographic and birth related co-variates

\begin{tabular}{ll}
\hline \multicolumn{1}{l}{ Check Box } \\
\hline Born premature & \\
\hline Yes & \\
\hline Born term low birth weight & \\
\hline No & \\
\hline Yes & \\
\hline Mother's education & \\
\hline Illiterate & \\
\hline Up-to secondary & \\
\hline Graduate & \\
\hline Mother's occupation & \\
\hline Working & \\
\hline Nonworking & \\
\hline
\end{tabular}

(D). Past history related co-variates with severe pneumonia

\begin{tabular}{ll}
\hline & Check Box \\
\hline Exclusive breastfeeding (till 6 months of age) & \\
\hline Yes & \\
\hline No & \\
\hline Vitamin A \\
supplementation
\end{tabular}




\begin{tabular}{ll}
\hline Kerosene ingestion & \\
\hline No & \\
\hline Yes & \\
\hline Antibiotic treatment & \\
\hline No & \\
\hline Yes & \\
\hline Hospitalization & \\
\hline No & \\
\hline Yes & \\
\hline Acyanotic congenital heart disease & \\
\hline Absent & \\
\hline Present & \\
\hline Home treatment tried (other than self-medication) \\
\hline Yes
\end{tabular}

\section{(E). Environmental covariates}

\begin{tabular}{lc}
\hline Type of family & Check Box \\
\hline Nuclear & \\
\hline Joint & \\
\hline Number of family members & \\
\hline Upto 5 & \\
\hline $5-10$ & \\
\hline$>10$ & \\
\hline Type of home & \\
\hline Pukka & \\
\hline Kuccha & \\
\hline Overcrowding & \\
\hline No & \\
\hline Yes & \\
\hline
\end{tabular}




\begin{tabular}{ll}
\hline Indoor air pollution & \\
\hline No & \\
\hline Yes & \\
\hline Poor ventilation in living area & \\
\hline No & \\
\hline Yes & \\
\hline Contact with TB & \\
\hline No & \\
\hline Yes & \\
\hline Smoking at home & \\
\hline No & \\
\hline Yes & \\
\hline Drinking water source & \\
\hline Onderground water & \\
\hline Open defecation & \\
\hline
\end{tabular}

\section{(F). Investigation:}

\begin{tabular}{cl}
\hline $\mathrm{Hb}$ & \\
\hline $\mathrm{TLC}$ & \\
\hline $\mathrm{DLC}$ & \\
\hline $\mathrm{I} / \mathrm{T}$ ratio & \\
\hline Platelet count & \\
\hline $\mathrm{CRP}$ & \\
\hline
\end{tabular}

\section{(G). Anthropometry}

\begin{tabular}{|c|c|c|c|}
\hline S.No. & Parameters & Actual & Expected \\
\hline 1. & Weight (in Kgs) & & \\
\hline 2. & Height & & \\
\hline 3. & Head Circumference & & \\
\hline 4. & Mid arm Circumference & & \\
\hline
\end{tabular}




\section{References}

1. UNICEF. One Is Too Many Ending Child Death from Pneumonia and Diarrhoea; UNICEF: New York, NY, USA, 2016; Available online: https://data.unicef.org/wp-content/uploads/2016/11/UNICEF-Pneumonia-Diarrhoeareport2016-web-version_final.pdf (accessed on 20 May 2020).

2. UNICEF. End Preventable Deaths: Global Action Plan for Prevention and Control of Pneumonia and Diarrhoea; World Health Organization: Geneva, Switzerland, 2013; Available online: http://apps.who.int/iris/bitstream/ha ndle/10665/79200/9789241505239_eng.pdf;jsessionid=837AEC1288C76D2368F1E8F8DAB86B55?sequence=1 (accessed on 20 May 2020).

3. WHO. Global Burden of Disease Estimates 2000-2015; WHO: Geneva, Switzerland, 2016; Available online: http://www.who.int/healthinfo/global_burden_disease/estimates/en/index2.html (accessed on 20 May 2020).

4. McAllister, D.A.; Liu, L.; Shi, T.; Chu, Y.; Reed, C.; Burrows, J.; Adeloye, D.; Rudan, I.; Black, R.E.; Campbell, H.; et al. Global, regional, and national estimates of pneumonia morbidity and mortality in children younger than 5 years between 2000 and 2015: A systematic analysis. Lancet Glob. Health 2019, 7, e47-e57. [CrossRef]

5. Lancet, T. The case for action on childhood pneumonia. Lancet 2017, 390, 2122. [CrossRef]

6. Tiewsoh, K.; Lodha, R.; Pandey, R.M.; Broor, S.; Kalaivani, M.; Kabra, S.K. Factors determining the outcome of children hospitalized with severe pneumonia. BMC Pediatr. 2009, 9, 15. [CrossRef]

7. Tazinya, A.A.; Halle-Ekane, G.E.; Mbuagbaw, L.T.; Abanda, M.; Atashili, J.; Obama, M.T. Risk factors for acute respiratory infections in children under five years attending the Bamenda Regional Hospital in Cameroon. BMC Pulm. Med. 2018, 18, 7. [CrossRef] [PubMed]

8. Sehgal, V.; Sethi, G.R.; Sachdev, H.P.; Satyanarayana, L. Predictors of mortality in subjects hospitalized with acute lower respiratory tract infections. Indian Pediatr. 1997, 34, 213-219. [PubMed]

9. Saha, S.; Hasan, M.; Kim, L.; Farrar, J.L.; Hossain, B.; Islam, M.; Ahmed, A.N.; Amin, M.R.; Hanif, M.; Hussain, M.; et al. Epidemiology and risk factors for pneumonia severity and mortality in Bangladeshi children $<5$ years of age before 10 -valent pneumococcal conjugate vaccine introduction. BMC Public Health 2016, 16, 1233. [CrossRef]

10. Onyango, D.; Kikuvi, G.; Amukoye, E.; Omolo, J. Risk factors of severe pneumonia among children aged 2-59 months in western Kenya: A case control study. Pan Afr. Med. J. 2012, 13, 45.

11. Lazzerini, M.; Seward, N.; Lufesi, N.; Banda, R.; Sinyeka, S.; Masache, G.; Nambiar, B.; Makwenda, C.; Costello, A.; McCollum, E.D.; et al. Mortality and its risk factors in Malawian children admitted to hospital with clinical pneumonia, 2001-12: A retrospective observational study. Lancet Glob. Health 2016, 4, e57-e68. [CrossRef]

12. Jroundi, I.; Mahraoui, C.; Benmessaoud, R.; Moraleda, C.; Tligui, H.; Seffar, M.; Kettani, S.E.; Benjelloun, B.S.; Chaacho, S.; Munoz-Almagro, C.; et al. Risk factors for a poor outcome among children admitted with clinically severe pneumonia to a university hospital in Rabat, Morocco. Int. J. Infect. Dis. 2014, 28, 164-170. [CrossRef]

13. Jakhar, S.K.; Pandey, M.; Shah, D.; Ramachandran, V.G.; Saha, R.; Gupta, N.; Gupta, P. Etiology and Risk Factors Determining Poor Outcome of Severe Pneumonia in Under-Five Children. Indian J. Pediatr. 2017. [CrossRef]

14. Hassan, M.K.; Al-Sadoon, I. Risk factors for severe pneumonia in children in Basrah. Trop. Dr. 2001, 31, 139-141. [CrossRef] [PubMed]

15. Fonseca Lima, E.J.; Mello, M.J.; Albuquerque, M.F.; Lopes, M.I.; Serra, G.H.; Lima, D.E.; Correia, J.B. Risk factors for community-acquired pneumonia in children under five years of age in the post-pneumococcal conjugate vaccine era in Brazil: A case control study. BMC Pediatr. 2016, 16, 157. [CrossRef] [PubMed]

16. Djelantik, I.G.; Gessner, B.D.; Sutanto, A.; Steinhoff, M.; Linehan, M.; Moulton, L.H.; Arjoso, S. Case fatality proportions and predictive factors for mortality among children hospitalized with severe pneumonia in a rural developing country setting. J. Trop. Pediatr. 2003, 49, 327-332. [CrossRef]

17. Cherian, T.; Mulholland, E.K.; Carlin, J.B.; Ostensen, H.; Amin, R.; de Campo, M.; Greenberg, D.; Lagos, R.; Lucero, M.; Madhi, S.A.; et al. Standardized interpretation of paediatric chest radiographs for the diagnosis of pneumonia in epidemiological studies. Bull. World Health Organ. 2005, 83, 353-359. [CrossRef] 
18. Collaborators, G.B.D.L.R.I. Quantifying risks and interventions that have affected the burden of lower respiratory infections among children younger than 5 years: An analysis for the Global Burden of Disease Study 2017. Lancet Infect. Dis. 2020, 20, 60-79. [CrossRef]

19. International Institute for Population Sciences. National Family Health Survey-4, 2015-16. District Fact Sheet Ujjain Madya Pradesh; International Institute for Population Sciences: Mumbai, India, 2016; p. 6.

20. WHO. Revised WHO Classification and Treatment of Childhood Pneumonia at Health Facilities. 2014. Available online: https://apps.who.int/iris/bitstream/handle/10665/137332/WHO_FWC_MCA_14.9_eng.pdf (accessed on 20 May 2020).

21. India Clinical Epidemiology Network(IndiaCLEN) Task Force on Pneumonia. Rational use of antibiotics for pneumonia. Indian Pediatr. 2010, 47, 11-18. [CrossRef]

22. Shah, S.S.; Shofer, F.S.; Seidel, J.S.; Baren, J.M. Significance of extreme leukocytosis in the evaluation of febrile children. Pediatr. Infect. Dis. J. 2005, 24, 627-630. [CrossRef]

23. Hildenwall, H.; Muro, F.; Jansson, J.; Mtove, G.; Reyburn, H.; Amos, B. Point-of-care assessment of C-reactive protein and white blood cell count to identify bacterial aetiologies in malaria-negative paediatric fevers in Tanzania. Trop. Med. Int. Health 2017, 22, 286-293. [CrossRef]

24. Jain, R.; Awasthi, S.; Awasthi, A. IMCI approach in tertiary hospitals, India. Indian J. Pediatr. 2009, 76, 725-727. [CrossRef]

25. Metz, C.E. Basic principles of ROC analysis. Semin. Nucl. Med. 1978, 8, 283-298. [CrossRef]

26. Akaike, H. A new look at the statistical model identification. IEEE Trans. Autom. Control 1974, 19, 716-723. [CrossRef]

27. Schwarz, G. Estimating the Dimension of a Model. Ann. Stat. 1978, 6, 461-464. [CrossRef]

28. Shah, S.N.; Bachur, R.G.; Simel, D.L.; Neuman, M.I. Does This Child Have Pneumonia?: The Rational Clinical Examination Systematic Review. JAMA 2017, 318, 462-471. [CrossRef] [PubMed]

29. Schot, M.J.C.; Dekker, A.R.J.; Giorgi, W.G.; Hopstaken, R.M.; de Wit, N.J.; Verheij, T.J.M.; Cals, J.W.L. Diagnostic value of signs, symptoms and diagnostic tests for diagnosing pneumonia in ambulant children in developed countries: A systematic review. NPJ Prim. Care Respir. Med. 2018, 28, 1-11. [CrossRef]

30. Dean, P.; Schumacher, D.; Florin, T.A. Defining Pneumonia Severity in Children: A Delphi Study. Pediatr. Emerg. Care 2020. [CrossRef]

31. Banstola, A.; Banstola, A. The epidemiology of hospitalization for pneumonia in children under five in the rural western region of Nepal: A descriptive study. PLoS ONE 2013, 8, e71311. [CrossRef]

32. Jullien, S.; Pradhan, D.; Tshering, T.; Sharma, R.; Dema, K.; Garcia-Garcia, S.; Ribo, J.L.; Munoz-Almagro, C.; Bassat, Q. Pneumonia in children admitted to the national referral hospital in Bhutan: A prospective cohort study. Int. J. Infect. Dis. 2020. [CrossRef]

33. Clark, J.E.; Hammal, D.; Hampton, F.; Spencer, D.; Parker, L. Epidemiology of community-acquired pneumonia in children seen in hospital. Epidemiol. Infect. 2007, 135, 262-269. [CrossRef]

34. Kabra, S.K.; Lodha, R. Antibiotics for preventing complications in children with measles. Cochrane Database Syst. Rev. 2013. [CrossRef]

35. Sadoh, W.E.; Osarogiagbon, W.O. Underlying congenital heart disease in Nigerian children with pneumonia. Afr. Health Sci. 2013, 13, 607-612. [CrossRef]

36. Khare, S.; Purohit, M.; Sharma, M.; Tamhankar, A.J.; Lundborg, C.S.; Diwan, V.; Pathak, A. Antibiotic Prescribing by Informal Healthcare Providers for Common Illnesses: A Repeated Cross-Sectional Study in Rural India. Antibiotics 2019, 8. [CrossRef] [PubMed]

37. Pathak, A.; Mahadik, K.; Dhaneria, S.P.; Sharma, A.; Eriksson, B.; Lundborg, C.S. Antibiotic prescribing in outpatients: Hospital and seasonal variations in Ujjain, India. Scand. J. Infect. Dis. 2011, 43, 479-488. [CrossRef] [PubMed]

38. Nhung, N.T.T.; Amini, H.; Schindler, C.; Kutlar Joss, M.; Dien, T.M.; Probst-Hensch, N.; Perez, L.; Kunzli, N. Short-term association between ambient air pollution and pneumonia in children: A systematic review and meta-analysis of time-series and case-crossover studies. Environ. Pollut 2017, 230, 1000-1008. [CrossRef] [PubMed]

39. Adaji, E.E.; Ekezie, W.; Clifford, M.; Phalkey, R. Understanding the effect of indoor air pollution on pneumonia in children under 5 in low- and middle-income countries: A systematic review of evidence. Environ. Sci. Pollut. Res. Int. 2019, 26, 3208-3225. [CrossRef] 
40. Florin, T.A.; Ambroggio, L.; Brokamp, C.; Zhang, Y.; Rattan, M.; Crotty, E.; Belsky, M.A.; Krueger, S.; Epperson, T.N.t.; Kachelmeyer, A.; et al. Biomarkers and Disease Severity in Children With Community-Acquired Pneumonia. Pediatrics 2020, 145. [CrossRef]

(C) 2020 by the authors. Licensee MDPI, Basel, Switzerland. This article is an open access article distributed under the terms and conditions of the Creative Commons Attribution (CC BY) license (http://creativecommons.org/licenses/by/4.0/). 